Oleksandr Matsenko,

Ph.D., Associate Professor, Sumy State University, Ukraine

(iD) ORCID ID, 0000-0002-1806-2811

email: amatsenko@econ.sumdu.edu.ua

Oleksandra Kubatko,

Ph.D., Associate Professor, Sumy State University, Ukraine

iD ORCID ID, 0000-0002-6869-7727

email: o.kubatko@econ.sumdu.edu.ua

Volodymyr Bardachenko,

Sumy State University, Ukraine

(iD) ORCID ID, 0000-0001-8474-6632

email: Bardachenko24@gmail.com

Kateryna Demchuk,

University of Applied Sciences of Hamburg, Germany

(iD) ORCID ID, 0000-0001-9556-1625

email: katerynademchuk@icloud.com

Correspondence author: amatsenko@econ.sumdu.edu.ua

\title{
TRANSFORMATION OF THE RESTAURANT BUSINESS AS A RESULT OF THE COVID-19 PANDEMIC: IMPROVING THE SECURITY OF SERVICE AND MAINTAINING THE HEALTH OF HUMAN CAPITAL
}

Abstract. The study identified socio-economic problems in the restaurant business, analyzed the dynamics of its decline and recovery during the pandemic COVID-19, considered innovative trends in the transformation of restaurant management. Systematization of literature sources and approaches to the study of the impact of epidemics and pandemics on restaurant activities showed that until 2019, cases of infection of restaurant visitors occurred. However, they were isolated or local (regional) in nature and attracted the attention of most medical researchers. The COVID19 pandemic is global in heart and has affected all economic areas, including the restaurant industry. Therefore, the number of scientific papers in this field is proliferating. The urgency of solving the scientific problem is that during the COVID-19 pandemic, restaurant customers' behavior and a significant increase in the number of online orders. This encourages restaurants to respond and transform their business models, business strategies and diversify sales channels. The research method is based on the statistical analysis of restaurant business performance indicators at the global level and the level of Ukraine and the analysis of innovative modern trends in the transformation of the restaurant business. The study results showed that the restaurant industry's main problems in the period of quarantine restrictions and lockdowns are mass layoffs, declining sales, inability to adapt and transform to the new conditions of the restaurant business. Accordingly, the directions of transformation of the restaurant business based on breakthrough innovations to increase customer service safety during the pandemic are proposed. The article focuses on the possibilities of restaurants to promote the health of human capital by diversifying the menu for vulnerable groups, such as children, people with chronic diseases, members of certain racial and ethnic minorities, the elderly. The results of this study can help build a policy in the restaurant industry to overcome the crisis in this area and improve public health. Also, the results can be used by restaurants to increase their competitiveness based on specific transformation measures.

Keywords: COVID-19, delivery, epidemic, health, pandemic, restaurant industry, restaurant service, restaurant business, transformation.

Cite as: Matsenko, O., Kubatko, O., Bardachenko, V., \& Demchuk, K. (2021). Transformation of the Restaurant Business as a Result of the COVID-19 Pandemic: Improving the Security of Service and Maintaining the Health of Human Capital. Health Economics and Management Review, 3, 27-38. http://doi.org/10.21272/hem.2021.3-03

27 
O., Matsenko, O., Kubatko, V., Bardachenko, K., Demchuk. Transformation of the Restaurant Business as a Result of the COVID-19 Pandemic: Improving the Security of Service and Maintaining the Health of Human Capital

Introduction. To reduce the rate of spread of the COVID-19 pandemic, governments worldwide have begun to impose restrictions aimed at eliminating direct human-to-human contact. Most of the mass measures were canceled, and one of the first industries to feel the effects of the pandemic was the restaurant industry. To contain the SARS-CoV-2 coronavirus pandemic, measures such as social distancing, self-isolation and travel restrictions have been introduced around the world. With the advent of the second wave of pandemics, the local level began to introduce so-called «red zones», where restaurants were forced to cease their traditional activities.

Many restaurants in the world and Ukraine could not return to their activities after quarantine. A study in the United States (Brizek et al., 2021) showed that 25\% of the restaurants surveyed did not survive the closure before two months. Less than a quarter of respondents were unable to return employees of their company to work as in the pre-pandemic period.

Nowadays, the behaviour of restaurant customers has changed: in most cases, they prefer separate tables or even rooms when visiting restaurants (Kim et al., 2020). Many people prefer to order food online. In connection with the pandemic, the restaurant business needs to develop and implement innovative services and digital management methods (Shtal et al., 2021). It is necessary to transform the distribution channels for ready-made food and, in general, change their business models.

This study aims to identify innovative areas and drivers of transformation of the restaurant business in times of crisis to improve the security of services and preserve the health of human capital.

Literature Review. Until 2019, scientific works in studying epidemics, viruses, or bacteria, the reason for the spread of which were visits to restaurants, were mostly purely medical in nature and were published in scientific journals in the medical field. They mainly studied local or regional cases of outbreaks, such as norovirus, salmonellosis, infectious hepatitis, botulism, gastroenteritis, and others. There were cases of coronavirus infection among them. Thus, one of the first scientifically analyzed cases of SARS coronavirus infection in 2004 was associated with restaurant workers (Che et al., 2006). However, these scientific works were mainly related to epidemics, as it was not about the mass nature of infections when the epidemic acquires pandemic status.

It has been proven that airborne droplets and droplets transmit the coronavirus through the air over long distances, which was studied on the territory of the restaurant (Kwon et al., 2020; Buonanno et al., 2020). The outbreak of COVID-19 has negatively impacted the restaurant industry and has resulted in significant and job losses. Articles have emerged pointing to a negative regression in the consumption of services in the restaurant industry, with an increase in the number of new cases of COVID-19 (Yang et al., 2020).

Figure 1 shows the structure of the publication activity of the authors who study the aspects of the impact of the COVID-19 pandemic on the restaurant industry. It was found that the interest in the consequences of the pandemic for the restaurant industry and the problems in this area is only growing: for the incomplete year 2021, 180 articles were published, and for the whole of 2020 - 88 (Figure 2). Scientists in almost all scientific fields are studying the impact of the COVID-19 pandemic. Most articles in this area were published in scientific journals related to the thematic areas of Medicine (30\%), Business, Management and Accounting (24\%) and Social Sciences (12\%).

Using Zotero and VOSviewer software, a bibliometric analysis of the scientific work of the Scopus database was conducted, which examined epidemics and pandemics that were in one way or another related to or affected the restaurant industry. The clustering of these studies was carried out (Figure 3), the chronology of scientific works was determined (Figure 4). The size of the circles reflects the frequency of use of the terms.

In total, 737 articles for the period 1965-2021 were analyzed. And although the COVID-19 pandemic arose only in 2019 , about $35 \%$ of articles are devoted to its impact on the restaurant industry. The literature analysis found that due to the transmission of the SARS-CoV-2 coronavirus by airborne droplets, the 
O., Matsenko, O., Kubatko, V., Bardachenko, K., Demchuk. Transformation of the Restaurant Business as a Result of the COVID-19 Pandemic: Improving the Security of Service and Maintaining the Health of Human Capital

COVID-19 pandemic differs from previous epidemics on a planetary scale, the clinical severity of the disease in infected individuals and the rate of spread of the infection among the population. To reduce the pandemic's peak in the early stages of the reach of COVID-19, most countries of the world have taken strict measures to isolate the population. As a result, the restaurant industry was unprepared to deal with the crisis.

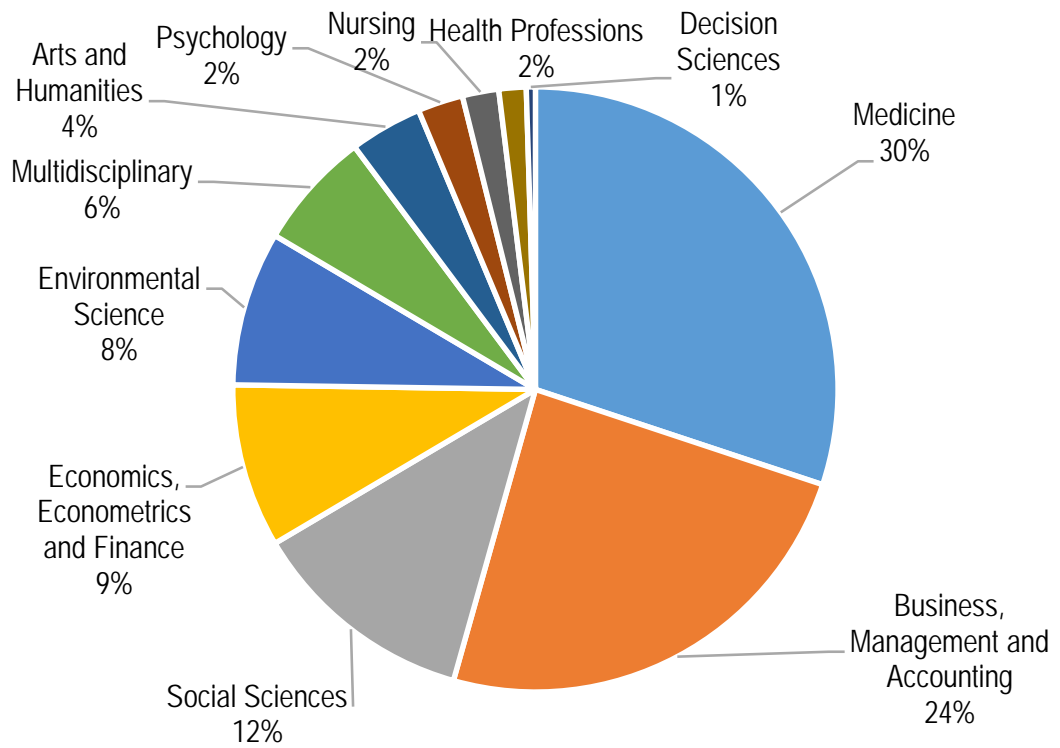

Figure 1. The structure of publishing activity of authors studying the impact of the COVID-19 pandemic on the restaurant industry in the areas of research

Sources: developed by the authors on the basis of Scopus database.

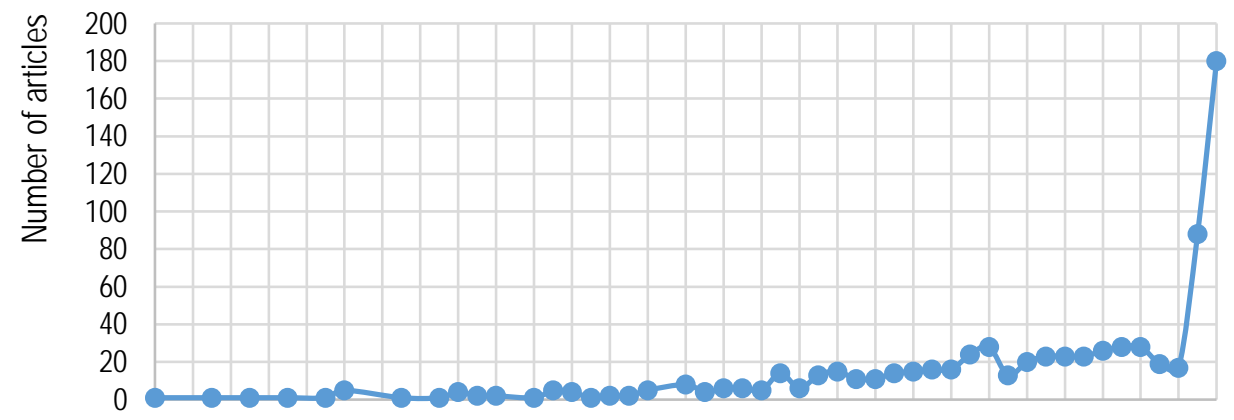

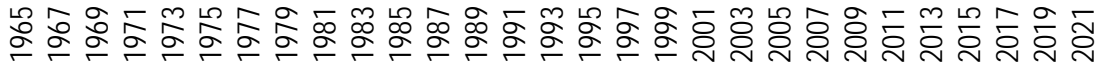

Year

Figure 2. Dynamics of the number of articles devoted to the study of restaurant activities during outbreaks of epidemics and pandemics

Sources: developed by the authors on the basis of Scopus database. 


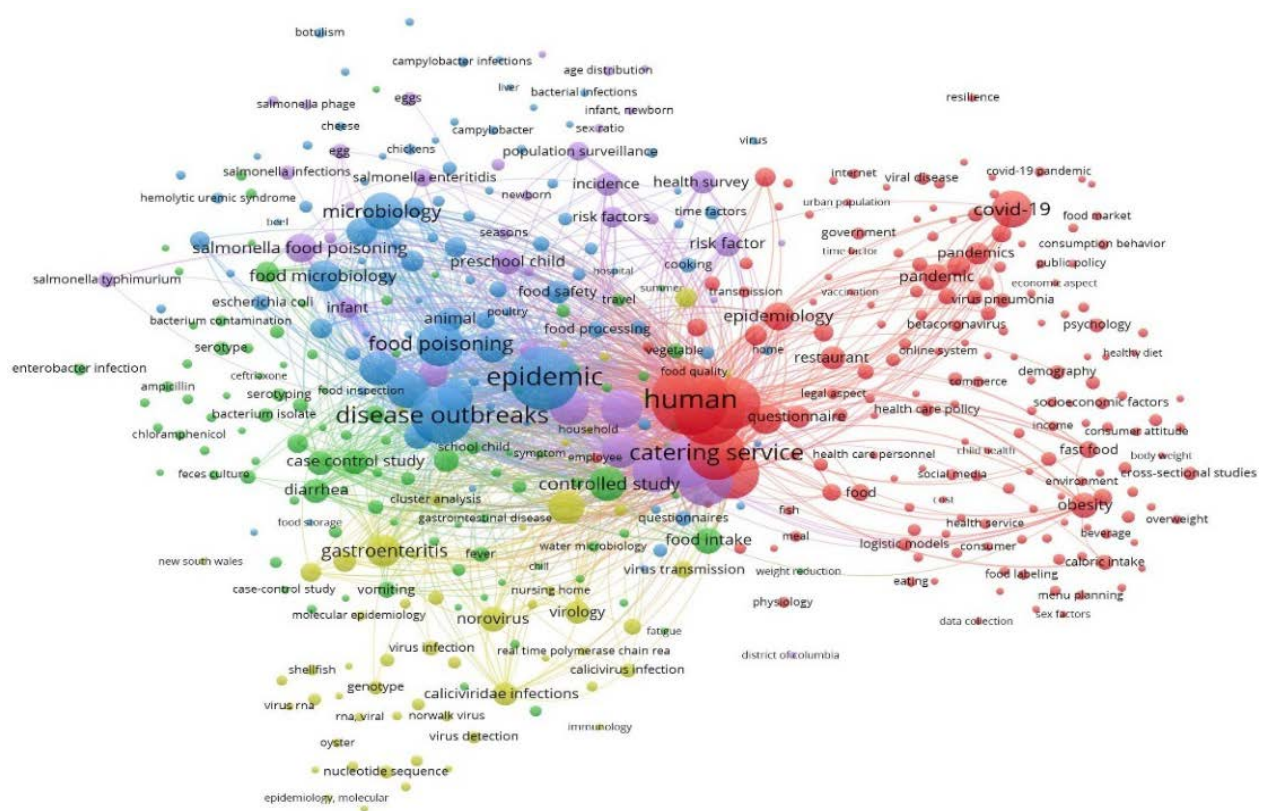

Figure 3. Bibliographic map of key terms in scientific articles devoted to the study of pandemics and epidemics related to the activities of restaurants

Sources: developed by the authors.

As a result of constructing a bibliographic map of key terms, 5 clusters (Figure 3 ) of scientific research were identified: the red cluster is related to works dedicated to studying the COVID-19 pandemic, which affected not most socio-economic spheres and humanity as a whole. The green cluster shows control studies of cases involving bacteria such as diarrhea. The yellow cluster characterizes large clinical studies of viral cases: norovirus, gastroenteritis, hepatitis A. The blue cluster includes studies of disease outbreaks, food-related epidemics, and methods to control them. The purple cluster combines studies of the risks of infection that are specific to different age and gender groups.

In Figure 4, the circles are coloured depending on the year of their publication. Terms that have received more attention in recent years have been painted more yellow.

Let's take a closer look at the effects of the COVID-19 pandemic on the restaurant industry over the past two years. The integrated impact of the COVID-19 pandemic on nutrition is discussed in (Leone et al., 2020; Zeb et al., 2021). The works (Kim et al., 2020; Song et al., 2021; Kim et al., 2021; Yost et al., 2021) investigated and proved the negative impact of outbreaks of epidemic diseases on the financial performance of the restaurant industry. The extent to which restaurants and food service workers have been affected and the role of government support for food service workers is analyzed in (Farrer, 2020; Madeira et al., 2021). The strengthening of the role of innovation in gourmet restaurants in the post-shaped period to increase their competitiveness based on differentiation is described in (Schwark et al., 2020; Gavilan et al., 2021).

Separate studies (Parfenov et al., 2021; Kumar and Shah, 2021) point to the need to transform the distribution channels for restaurant services in the context of the digitalization of the economy to ensure market success. Online-to-offline (O2O) trading volumes are growing (Yang et al., 2021). During a pandemic, people prefer to use mobile apps to order food from restaurants and protect themselves from 
O., Matsenko, O., Kubatko, V., Bardachenko, K., Demchuk. Transformation of the Restaurant Business as a Result of the COVID-19 Pandemic: Improving the Security of Service and Maintaining the Health of Human Capital

COVID-19 (Dirsehan and Cankat, 2021). Many restaurants have converted their business models to deliver via online platforms (Linh et al., 2021). Delivery services have been shown to increase the sustainability of restaurants (Neise et al., 2021).

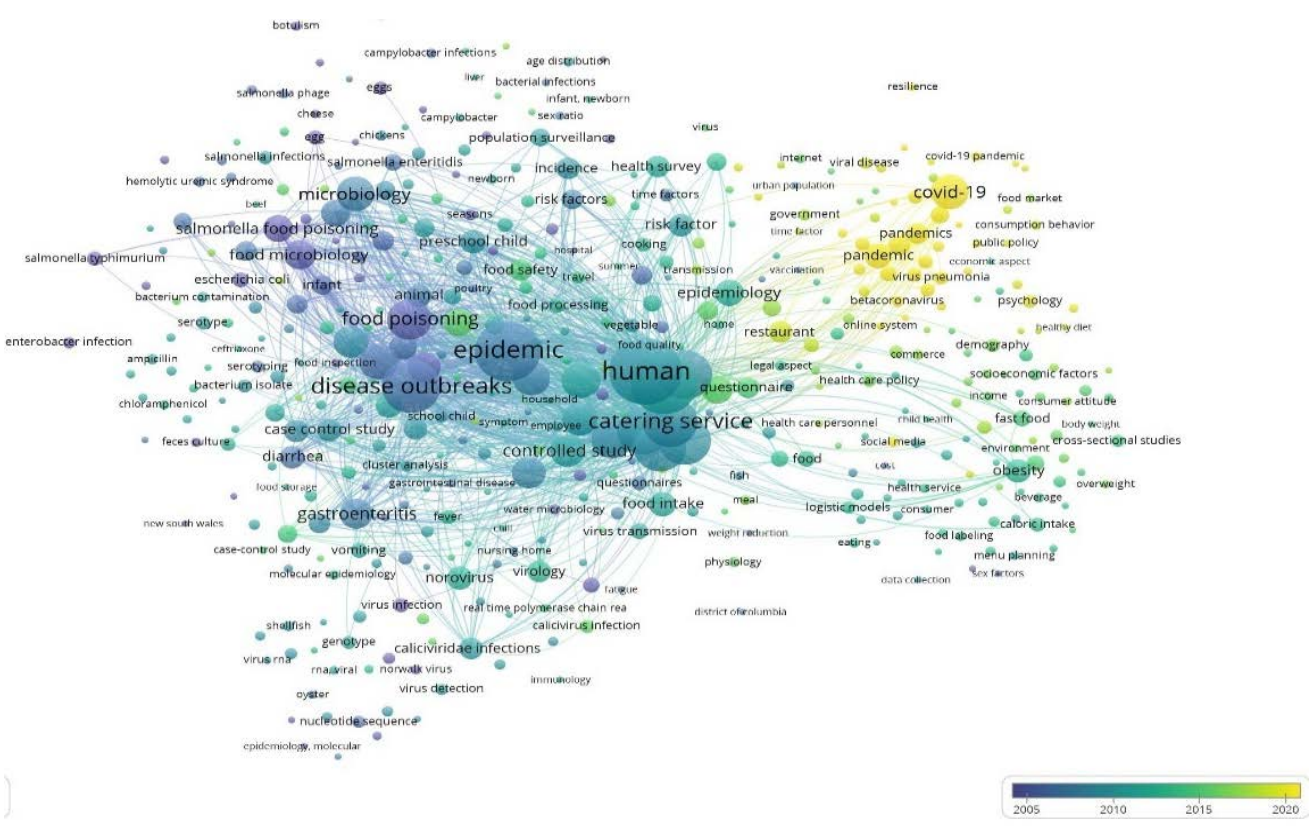

Figure 4. Visualization of the chronology of the studied terms

Sources: developed by the authors on the basis of Scopus database.

Methodology and research methods. The research method is based on the statistical analysis of restaurant business performance indicators at the global level and the level of Ukraine and the analysis of innovative modern trends in the transformation of the restaurant business. Among the general research methods should be deduced in the construction of the interdependence of parts and structure of work and induction in the formation of general conclusions of the study.

The study's hypothesis is the possibility of the restaurant business to transform its activities by increasing the level of security of restaurant visitors and contributing to the health of human capital by diversifying the menu for vulnerable groups.

The basis for the analysis were scientific articles of the Scopus database, open data of restaurant chains and official statistics.

Results. The tragic COVID-19 pandemic has changed socio-economic relations, especially in the service sector. Fear of direct physical contact and quarantine restrictions led to the bankruptcy of many restaurants, the loss of service staff, and the restaurant industry's income as a whole. At the beginning of the crisis, most restaurants had operating reserves for only two or three weeks, and these reserves were quickly depleted. Due to the lack of a deadline for mandatory closures, the owners promptly fired almost all staff, supporting the remaining crews.

Another critical factor that will affect the industry is the significant number of unemployed in general and the speed of their return to work in all sectors of the economy. When there is no work, free time allows former restaurant customers to cook more at home. 
O., Matsenko, O., Kubatko, V., Bardachenko, K., Demchuk. Transformation of the Restaurant Business as a Result of the COVID-19 Pandemic: Improving the Security of Service and Maintaining the Health of Human Capital

According to the US National Restaurant Association (Kim et al., 2021), about 8 million people, or about two-thirds of those working in the food industry, lost their jobs after the COVID-19 outbreak. Many waiters earn more by working than receiving unemployment benefits and want to return quickly but are worried that their incomes will fall due to reduced demand for restaurant services or strict quarantine restrictions. The industry's low profitability makes raising the salaries of restaurant workers virtually impossible in the absence of the possibility of raising menu prices, which customers who have been hit hard by the crisis are likely to refuse.

The downturn in the restaurant industry is affecting related industries, causing economic losses to farmers, fishers, gatherers, livestock farmers and other food producers. Supply chain partners also suffer losses. On the other hand, restaurants located in or near office complexes have suffered from reduced office occupancy and will continue to be negatively affected.

These factors are transforming the food industry, which is already different from the traditional one, which existed until early March 2020. Many restaurants have switched to the export and delivery of food, expanded their capacity to place on the side of the road and transfer orders at the entrance. Some have developed takeaway proposals with instructions for reheating or final cooking.

According to general estimates, more than $30-40 \%$ of restaurants will be closed forever, and others will need at least six months to restore to 2019. Thus, in Ukraine, the restaurant business lost almost $40 \%$ of operating establishments in 2020 (SSSU, 2021). The industry's problems are exacerbated by the emergence of new strains of coronavirus and the wave nature of the epidemic. The beginning of the crisis showed that most restaurants quickly depleted operating reserves (on average in 2-3 weeks) and began to reduce staff.

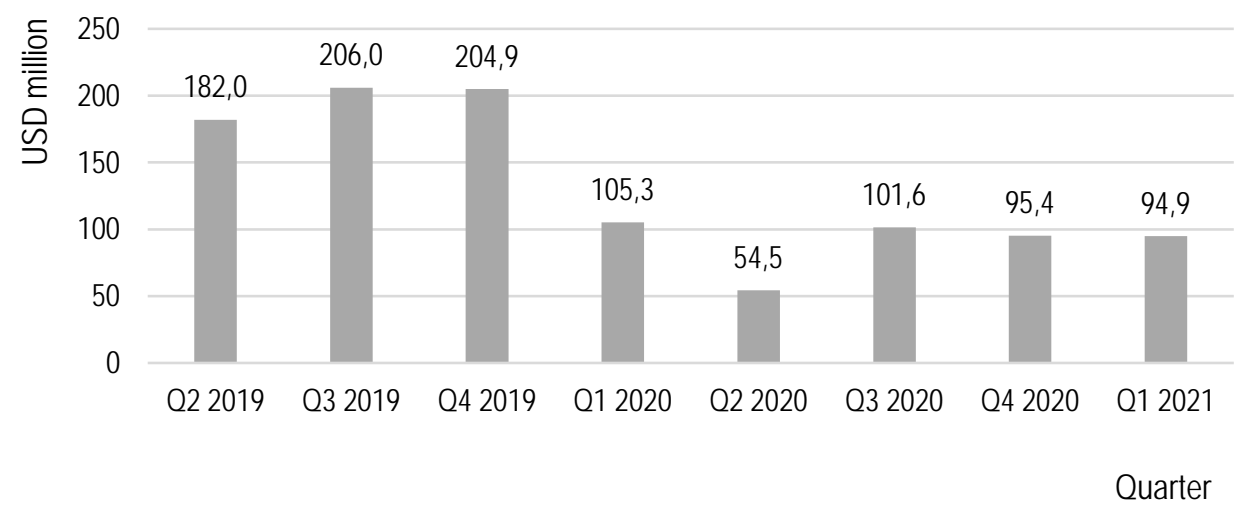

Figure 5. Dynamics of the volume of services provided by the restaurant industry, including mobile food services, million USD, Ukraine, 2nd quarter of 2019 - 1st quarter of 2021

Sources: developed by the authors on the basis of (SSSU, 2021).

In Ukraine, restrictions on COVID-19 have led to the decline of the restaurant industry, which has led to the search for new ways to provide restaurant services. During the fight against the COVID-19 pandemic, the role of Foodtech increased. The volume of the catering market in Ukraine in 2019 was estimated at 50 thousand points. During the «hard» quarantine in the country did not work about 30 thousand institutions. Therefore, the role of online food ordering and delivery has increased. In the first days of quarantine in Ukraine, the volume of orders in the Foodtech service increased by $80 \%$ compared to the normal functioning of the country (Markevych and Sidenko, 2021). 
O., Matsenko, O., Kubatko, V., Bardachenko, K., Demchuk. Transformation of the Restaurant Business as a Result of the COVID-19 Pandemic: Improving the Security of Service and Maintaining the Health of Human Capital

Globally, the restaurant industry is recovering to the level of 2019 , as evidenced by open data OpenTable (OpenTable, 2021). Figure 6 shows the number of seated visitors on a given day compared to the same day in 2019 (pre-pandemic period). The data are based on a sample of about 20 thousand restaurants around the world.

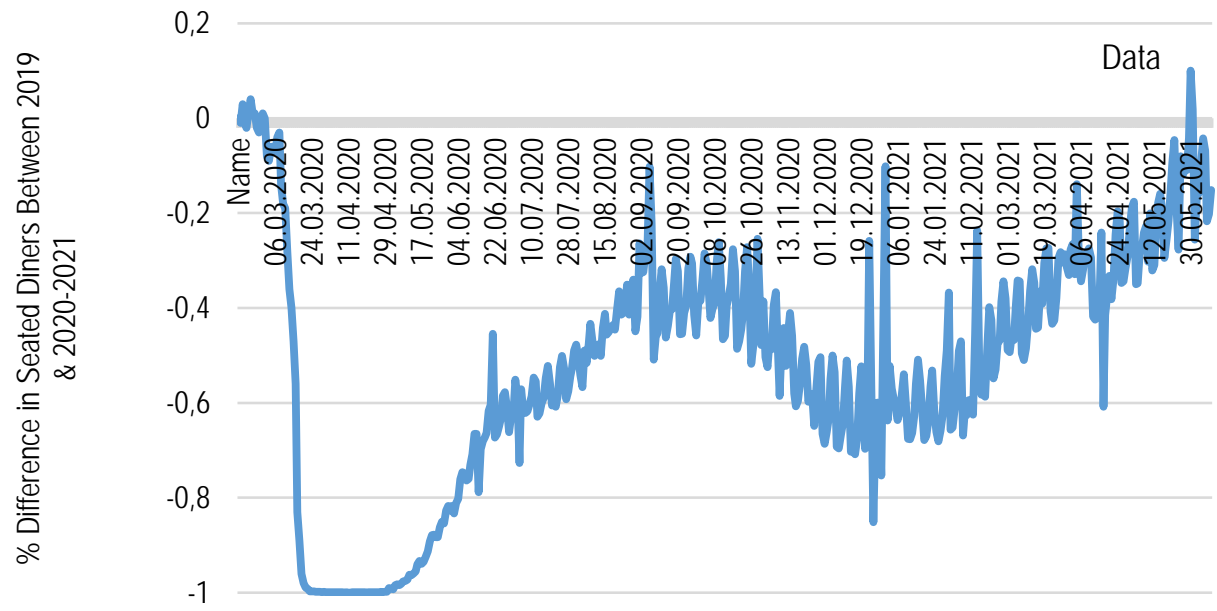

Figure 6. Dynamics of the number of sitting lunches compared to the same day in the prepandemic period of 2019

Sources: developed by the authors on the basis of (OpenTable, 2021).

From the plot, we see that the beginning of the recovery of the restaurant industry began around May 2020 after the first wave of coronavirus. The impact of the second wave of diseases in the winter of 20202021 is visible. The emergence of new strains of SARS virus only increases the likelihood of new waves of morbidity, quarantine measures and lockdowns. Restoration of demand for restaurant services indicates that the need for restaurant services among the population is present. Still, it is necessary to pay attention to the possibility of transformation of the restaurant business to preserve and stabilize it.

With the introduction of quarantine measures and red zones, restaurants were forced to respond. Figure 7 shows the most common tools and directions for counteracting the effects of a pandemic in the restaurant industry.

During the period of strict quarantine, restaurants ceased their traditional activities. In places where it is forbidden to receive visitors, the most effective way to save the restaurant business is to transform it into a fast-food industry. Takeaway and delivery have become the primary sources of income for restaurants. Emphasis should be placed on the quality of packaging to reduce the risk of bacteria entering the food, thereby increasing customer confidence. QR codes are becoming increasingly popular, and some visitors accept them as standard.

One of the reasons for the losses in the restaurant business is that people do not want to eat outside the home because they want to avoid contact with COVID-19 infection. This means that after an outbreak of SARS-CoV-2 infection, consumers tend to prefer home delivery services (Poelman et al., 2021). And although confidence in restaurants after quarantine is returning and many are ready to visit them (Hakim et al., 2021), restaurants should pay attention to innovations in food delivery logistics. In addition, restaurants should diversify their sales channels, diversifying menus and delivery options. 
O., Matsenko, O., Kubatko, V., Bardachenko, K., Demchuk. Transformation of the Restaurant Business as a Result of the COVID-19 Pandemic: Improving the Security of Service and Maintaining the Health of Human Capital

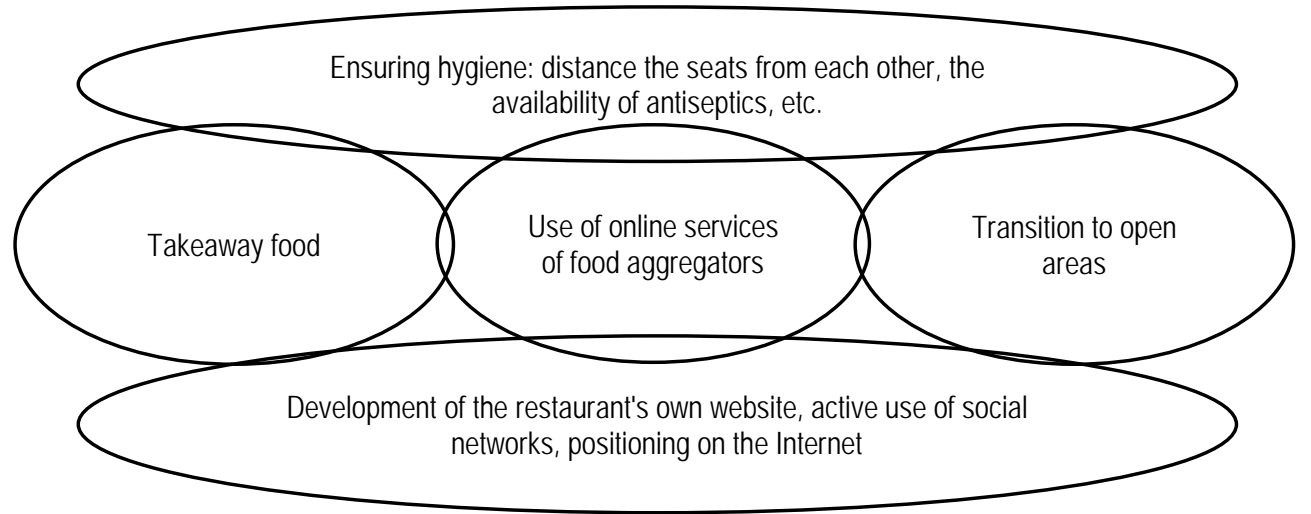

Figure 7. The most common measures for the reorganization of the restaurant industry Sources: developed by the authors.

The development of the digital economy has contributed to the cost of exchange processes, and a new value has come to the fore - data and information. Reasonable use of data allows you to respond quickly to customer requests, differentiate services by individual consumer groups, build a more complex and effective pricing policy. At the same time, restaurants are forced to attract specialists of new professions - analysts in the field of Big Data.

Recently, unmanned food delivery services, which are contactless services, are gaining popularity, attracting attention in the food industry, as they provide food without face-to-face meetings (Brizek et al., 2021). Robots and drones can be used for delivery. Humanoid robots, autonomous vehicles, drones and other intelligent robots are used in many ways to reduce contact with humans and sources of potential SARS-CoV-2 virus (Zeng et al., 2020).

According to experts, restaurants can optimize organizational decisions and business models and further satisfy visitors' interest in reducing the number of contact points with waiters and traditional physical menus. (Table 1) summarizes innovative solutions for the transformation of the restaurant business, which have already been implemented in practice (Melnyk et al., 2017; Melnyk et al., 2019; Hens et al., 2018; Hens et al., 2019).

The widespread fear for their safety and family, friends, colleagues and society has led to malnutrition in people. To relieve stress during the pandemic, people began to stock up on junk food with excessive amounts of salt and sugar. They stayed at home feeling bored, anxious and stressed, and sought relief from food (Kushner, 2020; Ahmed, 2020). Statistical research (Ahmed, 2020) confirms that social distancing and self-isolation during COVID-19 outbreaks affect people's weight gain. As a result of the transition of the majority of the population of countries to an isolated lifestyle, the risk of chronic diseases due to the inactivity of a person increases. As a result, many people continue to follow a specific diet in the post-hoc period to maintain a high level of immunity and cope with COVID-19 mutations. With declining human mobility and chronic diseases, health marketing is a very effective tool for maintaining the health of human capital (Tarkhov et al., 2012). Restaurants can support Post-quarantine dietary behavior (Zhang et al., 2020) by developing appropriate menus. This can be implemented even more efficiently and faster with government support (Figure 8). 
O., Matsenko, O., Kubatko, V., Bardachenko, K., Demchuk. Transformation of the Restaurant Business as a Result of the COVID-19 Pandemic: Improving the Security of Service and Maintaining the Health of Human Capital

Table 1. Innovative solutions in the restaurant business

\begin{tabular}{lll}
\hline Solutions (innovation) & Characteristic & Success in application \\
\hline Online food delivery & It is an innovative way of buying food & During the lockdown, $93 \%$ of large Italian cities
\end{tabular}

(online food delivery - that combines the social and personal served OFD, compared to only $74 \%$ in 2017, and OFD) needs of consumers. OFD takes place about one in two residents (47\%) can order ready through digital platforms such as Just meals online (in 2017, only $31 \%$ had such an Eat, Uber Eats and Glovo, which allow opportunity). During the 2019 coronavirus users to order food from several pandemic (COVID-19), food delivery costs different restaurants through an app or increased even more in several countries, website including Italy. Moreover, $40 \%$ of food retailers have experienced an increase in food delivery requests

Use of robots in the Service works began to be used The Korean delivery company, «People of field of delivery and alongside people in restaurants. The Delivery», has launched a service where robots service restaurant industry has automated the deliver food to homes. Customers order food process of preparing food for the through the delivery app, and delivery staff come service stage to the building and place food in the food storage room on the ground floor. Subsequently, the robot delivers food to the customer

Using drones to deliver One of the fastest-growing sectors in Uber began delivering food using drones in 2021 food recent times, and their use is growing in the restaurant industry

(Business, 2018). The company said consumers could get food at their doorstep in five to thirty minutes. Uber is not the first company to deliver food by drone. FoodPanda offers a delivery service using uncrewed aerial vehicles in 20 minutes within Hong Kong (Food, 2018). Dominos was the first large food chain to inspect food delivery by drone

Sources: developed by the authors on the basis of (Hwang et al., 2020; Amicarelli and Bux, 2020 Troise et al., 2020; Cha, 2020).

The use of health marketing will increase the competitiveness of restaurants and promote the health of human capital by empowering vulnerable groups such as children, people with chronic diseases, members of certain racial and ethnic minorities, and the elderly to order according to their needs. To do this, restaurants and aggregators need to modernize the interfaces and menus of their digital platforms.

Conclusions. The outbreak of coronavirus SARS-CoV-2 in Wuhan (China) in 2019 attracted the world's attention, and almost all sectors of the economy have undergone transformational changes due to the global pandemic. The events that took place due to the spread of COVID-19 have made their adjustments in the life and work of everyone. One industry that has undergone the most significant influence and transformational changes has been the restaurant industry.

The COVID-19 pandemic and quarantine measures have become a challenge for the restaurant business and the industry as a whole. For the most part, Restaurants did not have a balanced exit strategy on the one hand, and on the other, harsh government action, such as time limits or indefinite closures, undermined their viability. As a result, the restaurant business has been hit hard by the pandemic. Recovery will be long and painfully slow. Restaurateurs are learning new business models and adapting to new ways of doing business to overcome the devastating financial impact of the COVID-19 pandemic. Digitally innovative technologies and digital marketing enable restaurants to make a digital transformation. More and more restaurants are registering on the platforms of online aggregators, developing their websites, maintaining pages on social networks, managing information about their locations in Google Maps. 
O., Matsenko, O., Kubatko, V., Bardachenko, K., Demchuk. Transformation of the Restaurant Business as a Result of the COVID-19 Pandemic: Improving the Security of Service and Maintaining the Health of Human Capital

But more groundbreaking innovations are being used for transformation - robots and drones that nullify direct contact between people.

State provision of tax incentives, grants, concessional lending, etc. to stimulate restaurants and registrars to provide catering services to vulnerable groups of the population

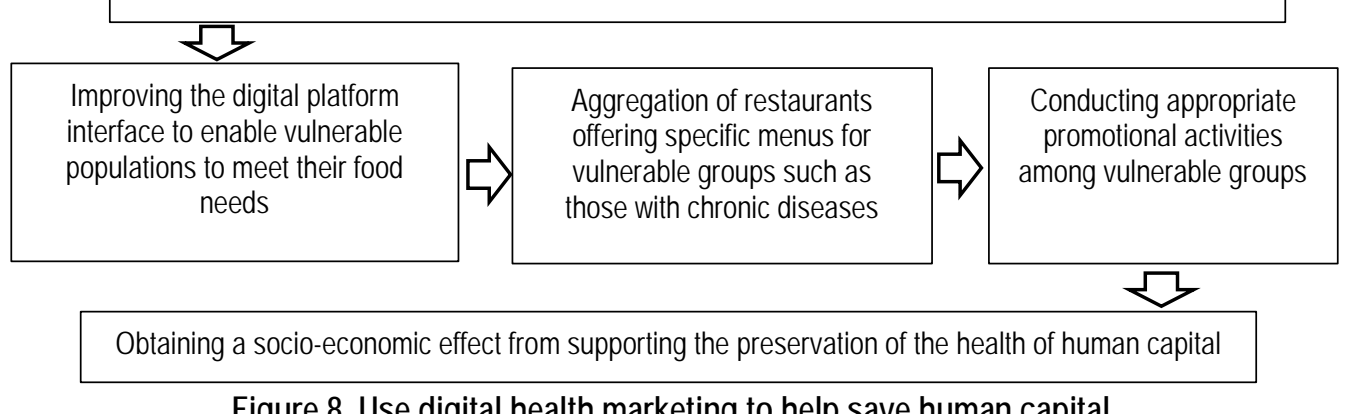

Figure 8. Use digital health marketing to help save human capital

Sources: developed by the authors.

The most successful restaurants can change quickly, flexibly adapt to new market environment requirements, implement innovative business models and make the right decisions.

Author Contributions: conceptualization, O. M.; methodology, O. K.; validation, O. M.; formal analysis, O. M.; investigation, O. M. and V. B.; data curation, O. M.; writing-original draft preparation, O. M. and $\mathrm{O}$. K.; writing-review and editing, O. M.; visualization, O. M.; supervision, O. K.; project administration, O. M.; funding acquisition, V. B.

Funding: The paper is prepared within the scientific research project «Fundamentals of the phase transition to the additive economy: from disruptive technologies to institutional socialization of decisions» (No. 0121U109557), funded by the general fund of the state budget of Ukraine.

\section{References}

Ahmed, H. O. (2020). The impact of social distancing and self-isolation in the last corona COVID-19 outbreak on the body weight in Sulaimani governorate-Kurdistan/lraq, a prospective case series study. Annals of medicine and surgery, 59, 110-117. [Google Scholar] [CrossRef]

Amicarelli, V., \& Bux, C. (2021). Food waste in Italian households during the Covid-19 pandemic: a self-reporting approach. Food Security, 13(1), 25-37. [Google Schoolar] [CrossRef]

Brizek, M. G., Frash, R. E., McLeod, B. M., \& Patience, M. O. (2021). Independent restaurant operator perspectives in the wake of the COVID-19 pandemic. International Journal of Hospitality Management, 93, 102766. [Google Scholar] [CrossRef]

Buonanno, G., Morawska, L., \& Stabile, L. (2020). Quantitative assessment of the risk of airborne transmission of SARS-CoV2 infection: prospective and retrospective applications. Environment international, 145, 106112. [Google Scholar] [CrossRef]

Business Insider. (2018). Uber May Start Delivering Burgers by Drones as soon as 2021 because Its CEO Says We Need Flying Burgers. Retrieved from [Link]

Cha, S. S. (2020). Customers' intention to use robot-serviced restaurants in Korea: relationship of coolness and $\mathrm{MCl}$ factors. International Journal of Contemporary Hospitality Management, 32(9), 2947-2968. [Google Scholar] [CrossRef]

Che, X. Y., Di, B., Zhao, G. P., Wang, Y. D., Qiu, L. W., Hao, W., ... \& Yuen, K. Y. (2006). A patient with asymptomatic severe acute respiratory syndrome (SARS) and antigenemia from the 2003-2004 community outbreak of SARS in Guangzhou, China. Clinical Infectious Diseases, 43(1), 1-5. [Google Scholar] [CrossRef]

Dirsehan, T., \& Cankat, E. (2021). Role of mobile food-ordering applications in developing restaurants' brand satisfaction and loyalty in the pandemic period. Journal of Retailing and Consumer Services, 62, 102608. [Google Scholar] [CrossRef]

Farrer, J. (2020). A Tokyo restaurant community faces Covid-19. Etnografia e ricerca qualitativa, 13(2), 245-254. [Google Scholar] [CrossRef] 
O., Matsenko, O., Kubatko, V., Bardachenko, K., Demchuk. Transformation of the Restaurant Business as a Result of the COVID-19 Pandemic: Improving the Security of Service and Maintaining the Health of Human Capital

Food and Wine Sherman, E. (2018). Uber Will Test Food Delivery by Drone. Retrieved from [Link]

Gavilan, D., Balderas-Cejudo, A., Fernández-Lores, S., \& Martinez-Navarro, G. (2021). Innovation in online food delivery: Learnings from COVID-19. International Journal of Gastronomy and Food Science, 24, 100330. [Google Scholar] [CrossRef]

Hakim, M. P., Zanetta, L. D. A., \& da Cunha, D. T. (2021). Should I stay, or should I go? Consumers' perceived risk and intention to visit restaurants during the COVID-19 pandemic in Brazil. Food Research International, 141, 110152. [Google Scholar] [CrossRef Hens, L., Karintseva, O., Kharchenko, M., \& Matsenko, O. (2018). The state's structural policy innovations influenced by the ecological transformations. Marketing and Management of Innovations, (3), 290-301. [Google Scholar] [CrosssRef]

Hens, L., Melnyk, L., Matsenko, O., Chygryn, O., \& Gonzales, C. C. (2019). Transport economics and sustainable development in Ukraine. Marketing and Management of Innovations, (3), 272-284. [Google Scholar] [CrossRef]

Hwang, J., Kim, D., \& Kim, J. J. (2020). How to Form Behavioral Intentions in the Field of Drone Food Delivery Services: The Moderating Role of the COVID-19 Outbreak. International Journal of Environmental Research and Public Health, 17(23), 9117. [Google Scholar] [CrossRef]

Kim, J., \& Lee, J. C. (2020). Effects of COVID-19 on preferences for private dining facilities in restaurants. Journal of Hospitality and Tourism Management, 45, 67-70. [Google Scholar] [CrossRef]

Kim, J., Kim, J., \& Wang, Y. (2021). Uncertainty risks and strategic reaction of restaurant firms amid COVID-19: Evidence from China. International Journal of Hospitality Management, 92, 102752. [Google Scholar] [CrossRef]

Kim, J., Kim, J., Lee, S. K. \& Tang, L. R. (2020). Effects of epidemic disease outbreaks on financial performance of restaurants: Event study method approach. Journal of Hospitality and Tourism Management, 43, 32-41. [Google Scholar] [CrossRef]

Kumar, S., \& Shah, A. (2021). Revisiting food delivery apps during COVID-19 pandemic? Investigating the role of emotions. Journal of Retailing and Consumer Services, 62, 102595. [Google Scholar] [CrossRef]

Kushner, R. F. (2020). What COVID-19 is Teaching Us About Counseling for Weight Management. Obesity (Silver Spring), 2036-2037. [Google Scholar] [CrossRef]

Kwon, K. S., Park, J. I., Park, Y. J., Jung, D. M., Ryu, K. W., \& Lee, J. H. (2020). Evidence of long-distance droplet transmission of SARS-CoV-2 by direct air flow in a restaurant in Korea. Journal of Korean medical science, 35(46). [Google Scholar] [CrossRef]

Leone, L. A., Fleischhacker, S., Anderson-Steeves, B., Harper, K., Winkler, M., Racine, E., ... \& Gittelsohn, J. (2020). Healthy food retail during the COVID-19 pandemic: Challenges and future directions. International journal of environmental research and public health, 17(20), 7397. [Google Scholar] [CrossRef]

Linh, D. H., Dung, N. D., Son, H. N., \& Kingsbury, A. (2021). The Responses of Consumers to the Online Ordering and Delivery of Meals by Restaurants During COVID-19: A Case Study of Thai Nguyen City, Vietnam. Journal of Electronic Commerce in Organizations (JECO), 19(3), 65-84. [Google Scholar] [CrossRef]

Madeira, A., Palrão, T., \& Mendes, A. S. (2021). The Impact of Pandemic Crisis on the Restaurant Business. Sustainability, 13(1), 40. [Google Scholar] [CrossRef]

Markevych, K., \& Sidenko, V. (2021). Smart-infrastructure in sustainable urban development: world experience and prospects of Ukraine. Razumkov Center. Retrieved from [Link]

Melnyk, L., Dehtyarova, I., Gorobchenko, D., \& Matsenko, O. (2017). Innovations in the context of modern economic transformation processes of enterprise, region, country: the EU experience. Marketing and management of innovations, 4, 260-271. [Google Scholar] [CrossRef]

Melnyk, L., Derykolenko, O., Kubatko, O. \& Matsenko, O. (2019). Business Models of Reproduction Cycles for Digital Economy. Proceedings of the 15th International Conference on ICT in Education, Research and Industrial Applications. Integration, Harmonization and Knowledge Transfer. Volume II. Kherson: CEUR-WS. Retrieved from [Link]

Neise, T., Verfürth, P., \& Franz, M. (2021). Rapid responding to the COVID-19 crisis: Assessing the resilience in the German restaurant and bar industry. International Journal of Hospitality Management, 96, 102960. [Google Scholar] [CrossRef]

OpenTable. (2021). The restaurant industry in recovery. Retrieved from [Link]

Parfenov, A., Shamina, L., Niu, J., \& Yadykin, V. (2021). Transformation of distribution logistics management in the digitalization of the economy. Journal of Open Innovation: Technology, Market and Complexity, 7(1), 1-13. [CrossRef]

Poelman, M. P., Gillebaart, M., Schlinkert, C., Dijkstra, S. C., Derksen, E., Mensink, F., ... \& de Vet, E. (2021). Eating behavior and food purchases during the COVID-19 lockdown: A cross-sectional study among adults in the Netherlands. Appetite, 157, 105002. [Google Scholar] [CrossRef]

Schwark, N., Tiberius, V., \& Fabro, M. (2020). How Will We Dine? Prospective Shifts in International Haute Cuisine and Innovation beyond Kitchen and Plate. Foods, 9(10), 1369. [Google Scholar] [CrossRef]

Shtal, T. V., Staverska, T. O., Svitlichna, V. Y., Kravtsova, S. V., Kraynyuk, L. N., \& Pokolodna, M. M. (2021). Digitalization as a Tool for Ensuring Innovative Development of Restaurant Business. Estudios de economía aplicada, 39(5), 19. [Google Scholar]

Song, H. J., Yeon, J., \& Lee, S. (2021). Impact of the COVID-19 pandemic: Evidence from the US restaurant industry. International Journal of Hospitality Management, 92, 102702. [Google Scholar] [CrossRef] SSSU. (2021). Official site. Retrieved from [Link]

Tarkhov, P. V., Matsenko, A. M., Krugliak, A. P., \& ZhV, D. (2012). Provision of integrity and reliability in hygienic examination of investment projects for human capital development. Gigiena i sanitariia, (5), 91-94. [Google Scholar]

Troise, C., O'Driscoll, A., Tani, M., \& Prisco, A. (2020). Online food delivery services and behavioural intention-a test of an integrated TAM and TPB framework. British Food Journal. [Google Scholar] [CrossRef] 
O., Matsenko, O., Kubatko, V., Bardachenko, K., Demchuk. Transformation of the Restaurant Business as a Result of the COVID-19 Pandemic: Improving the Security of Service and Maintaining the Health of Human Capital

Yang, F. X., Li, X., Lau, V. M. C., \& Zhu, V. Z. (2021). To survive or to thrive? China's luxury hotel restaurants entering 020 food delivery platforms amid the COVID-19 crisis. International Journal of Hospitality Management, 94, 102855. [Google Scholar] [CrossRef

Yang, Y., HongBo, L., \& Xiang, C. (2020). COVID-19 and restaurant demand: early effects of the pandemic and stay-at-home orders. International Journal of Contemporary Hospitality Management, 32(12), 3809-3834. [Google Scholar]

Yost, E., Kizildag, M., \& Ridderstaat, J. (2021). Financial recovery strategies for restaurants during COVID-19: Evidence from the US restaurant industry. Journal of Hospitality and Tourism Management, 47, 408-412. [Google Scholar] [CrossRef]

Zeb, S., Hussain, S. S., \& Javed, A. (2021). COVID-19 and a way forward for restaurants and street food vendors. Cogent Business \& Management, 8(1), 1923359. [Google Scholar] [CrossRef]

Zeng, Z., Chen, P. J., \& Lew, A. A. (2020). From high-touch to high-tech: COVID-19 drives robotics adoption. Tourism Geographies, 22(3), 724-734. [Google Scholar] [CrossRef]

Zhang, J., Zhao, A., Ke, Y., Huo, S., Ma, Y., Zhang, Y., ... \& Liu, K. (2020). Dietary behaviors in the post-lockdown period and its effects on dietary diversity: the second stage of a nutrition survey in a longitudinal Chinese study in the COVID-19 era. Nutrients, 12(11), 3269. [Google Scholar] [CrossRef]

Олександр Маценко, к.е.н., доцент, Сумський державний університет, Україна

Олександра Кубатко, к.е.н., доцент, Сумський державний університет, Україна

Володимир Бардаченко, Сумський державний університет, Україна

Катерина Демчук, Університет прикладних наук Гамбурга, Німеччина

Трансформація ресторанного бізнесу внаслідок пандемії COVID-19: підвищення безпеки обслуговування та збереження здоров'я людського капіталу

У ході проведеного дослідження було виявлено соціально-економічні проблеми у ресторанному бізнесі, проаналізовано динаміку його спаду та відновлення в період пандемії COVID-19, розглянуто інноваційні тренди у транссрормаціях управління ресторанним бізнесом. Систематизаиія літературних джерел та підходів до дослідження впливу епідемій та пандемій на ресторанну діяльність засвідчила, що до 2019 р. випадки зараження відвідувачів ресторанів траплялися, але вони носили поодинокий або локальний (регіональний) характер та приверстали увагу переважно дослідників з медицини. Пандемія COVID-19 носить глобальний характер і вплинула на всі економічні сфери діяльності, у тому числі, й на ресторанну галузь. Тому кількість наукових праць у цій сффері стрімко зростає. Актуальність вирішення наукової проблеми полягає в тому, що в період пандемії COVID-19 відбулися зміни у поведінці клієнтів ресторанів і значно зросла кількість онлайн замовлень. Це спонукає ресторани реагувати і трансформувати свої бізнес-моделі, стратегіі діяльності та диверсифбікувати канали збуту. Метод дослідження базується на статистичному аналізі показників діяльності ресторанного бізнесу на глобальному рівні та рівні України, а також на аналізі сучасних інноваційних трендів трансфрормації ресторанного бізнесу. Результати дослідження показали, що основними проблемами ресторанно індустрії в період карантинних обмежень та локдаунів $є$ масові звільнення, зниження продажів, неспроможність адаптуватися та трансформуватися до нових умов ведення ресторанного бізнесу. Відповідно запропоновано напрями транссоормації ресторанного бізнесу на основі проривних інновацій з метою підвищення безпеки обслуговування клієнтів в період пандемії. У статті приділено увагу можливостям ресторанів сприяти збереженню здоров'я людського капіталу шляхом диверсифікації меню для вразливих груп населення, таких як діти, люди з хронічними захворюваннями, представники певних расових і етнічних меншин, літні люди. Результати проведеного дослідження можуть бути корисними для побудови політики у сфрері ресторанної індустрії з метою подолання у цій сфері кризових явищ та покращити суспільне здоров'я. Також результати можуть бути використані ресторанами для підвищення їх конкурентоспроможності на основі конкретних транссормаційних заходів.

Ключові слова: COVID-19, здоров'я, епідемія, пандемія, ресторанна індустрія, ресторанна послуга, ресторанний бізнес, трансформація, доставка. 